Marquette University

e-Publications@Marquette

Psychology Faculty Research and Publications

Psychology, Department of

11-1-2009

Latino Definitions of Success: A Cultural Model of Intercultural Competence

Lucas Torres

Marquette University, lucas.torres@marquette.edu

Accepted version. Hispanic Journal of Behavioral Sciences, Vol. 31, No. 4 (November 2009): 576-593.

DOI. (C) 2009 SAGE Publications. Used with permission. 
NOT THE PUBLISHED VERSION; this is the author's final, peer-reviewed manuscript. The published version may be accessed by following the link in the citation at the bottom of the page.

\title{
Latino Definitions of Success: A Cultural Model of Intercultural Competence
}

\author{
Lucas Torres \\ Department of Psychology, Marquette University \\ Milwaukee, WI
}

\begin{abstract}
The present study sought to examine Latino intercultural competence via two separate methodologies. Phase 1 entailed discovering and generating themes regarding the features of intercultural competence based on semistructured interviews of 15 Latino adults. Phase 2 included conducting a cultural consensus analysis from the quantitative responses of 46 Latino adults to determine the cultural model of intercultural competence. The major results indicated that the participants, despite variations in socioeconomic and generational statuses, shared a common knowledge base regarding the competencies needed for Latinos to successfully navigate different cultures. Overall, the cultural model of Latino intercultural competence includes a set of skills that integrates traditional cultural values along with attributes of self-efficacy. The findings are discussed within a competence-based conceptualization of cultural adaptation and potential advancements in acculturation research.
\end{abstract}

Keywords: intercultural competence, acculturation, Latino mental health, mixed-methodology

Strong waves of immigration along with relatively high birthrates have resulted in large numbers of Latinos living in the United States. These individuals are faced with having to navigate the

Hispanic Journal of Behavioral Sciences, Vol 31, (2009): pg. 357-593. DOI. This article is (C) SAGE Publications and permission has been granted for this version to appear in e-Publications@Marquette. SAGE Publications does not grant permission for this article to be further copied/distributed or hosted elsewhere without the express permission from SAGE Publications. 
mainstream U.S. culture as well as their growing and changing ethnocultural enclaves. In order to successfully negotiate these different cultural contexts, individual must develop a set of skills that promotes effective adaptation. This process can be stressful, with uncertain ends, and therefore carries a mental health risk. Current assessments of cultural adaptation, particularly acculturation, have not fully captured the complexities that occur when interacting with various cultures and/or have not adequately defined "successful adaptation," let alone identified the requisite skills (Ward, 2001). The current study sought to examine the shared knowledge or understanding of Latino intercultural competence, or the skills that facilitate cultural interactions, via a mixed-methods approach. The qualitative portion of the project identified emergent themes, from semi-structured interviews of Latino adults in the community, detailing the features of intercultural competence. Then, cultural consensus analysis (Romney, Weller, \& Batchelder, 1986), an innovative methodological procedure from the field of anthropology, was used to identify the shared cultural model of Latino intercultural competence. The value of the present research is to clarify the experiences of the Latino group, which has particular significance to the current U.S. demography and sociopolitical context as well as to contribute to the general modeling of the cultural adaptation process.

The empirical research investigating the experience of navigating separate cultures has primarily focused on acculturation, defined as the phenomenon that occurs when different cultural groups come into continuous contact with subsequent changes in the original cultural patterns of either or both groups (Redfield, Linton, \& Herskovits, 1936). Although several theoretical advances have been made (i.e., bidimensional vs. unidimensional perspectives; see Berry, 2003), the measurement of acculturation relies on aspects of cultural exposure and cultural knowledge that, along with more simplistic indicators of adjustment (e.g., socioeconomic status, generation level), give an estimate of global group trends. Perhaps as a consequence, previous research has reported discrepant findings regarding the relationship between acculturation and Latino mental health (see Rogler, Cortes, \& Malgady, 1991). Padilla and Perez (2003) noted that previous acculturation models and research have been hampered by a static view of intergroup relations, a belief that adaptation is a uniform process and methodological practices that have focused on language

Hispanic Journal of Behavioral Sciences, Vol 31, (2009): pg. 357-593. DOI. This article is (C) SAGE Publications and permission has been granted for this version to appear in e-Publications@ Marquette. SAGE Publications does not grant permission for this article to be further copied/distributed or hosted elsewhere without the express permission from SAGE Publications. 
preferences and entertainment/friendship patterns. Overall, acculturation studies focus on what changes occur in an individual's life during cultural adaptation but overlook how these processes take place.

Although newer acculturation scales assess certain behavioral aspects of adaptation, they do not address some of the nuances involved in negotiating different cultures. For instance, an individual's preferences for associating with members of the mainstream U.S. and/or traditional Latino cultures are measured in many acculturation scales. However, the nature of these interactions is not typically examined. The repertoire of skills and method by which an individual approaches a social situation is influenced on whether establishing network connections or maintaining supportive friendships is the valued outcome of that cultural contact. Ward (2001) has argued that adaptation is, in part, a result of learning the culture-specific skills that are needed to negotiate different cultural contexts. Ultimately, it is the success or failures of many person-environment interactions that contributes to an individual effectively navigating within and between cultures.

In their presentation of an innovative model, Padilla and Perez (2003) suggested that cultural competence is one of the pillars of acculturation. Generally speaking, cultural competence, or knowledge about and ability to function in a particular culture, has been thought of as a unique and understudied aspect of cultural adaptation (Zea et al., 2003). Competence-based formulations of cultural adaptation emphasize that a mastery of particular sets of functional skills is key to well-being and allow individuals to fulfill societal roles effectively (LaFromboise, Coleman, \& Gerton, 1993; Ogbu, 1981). A measure of intercultural competence concerns has been developed as a subscale of the Cultural Adjustment Difficulties Checklist (CADC) that was intended to understand the acculturative stress factors associated with immigrating to the United States within the Asian population (Sodowsky \& Lai, 1997). This sub-scale addresses concerns regarding broad areas including social, cultural as well as academic and career competence. The Intercultural Competence Concerns subscale of the CADC has been used with Latino populations showing that it makes significant contributions to the mental health of this group (Torres \& Rollock, 2004; Torres, 2009). However, a rigorous assessment of the

Hispanic Journal of Behavioral Sciences, Vol 31, (2009): pg. 357-593. DOI. This article is (C) SAGE Publications and permission has been granted for this version to appear in e-Publications@Marquette. SAGE Publications does not grant permission for this article to be further copied/distributed or hosted elsewhere without the express permission from SAGE Publications. 
specific skills that define Latino intercultural competence, as described by members of the community, has yet to be conducted. It is necessary to understand the characteristics of intercultural competence, as defined by the Latino community, rather than outlining adaptation strategies that have been drawn from a mainstream frame of reference, as done in previous work.

\section{Present Study}

Historically, qualitative strategies have been the primary method used to discover the characteristics underlying a particular cultural process. Despite the richness of information obtained from qualitative methods, several limitations have emerged regarding the use of nonsystematic and nonstatistical procedures. Recent trends in the empirical literature have focused on mixed-methodology to triangulate results as well as to facilitate discovery and testing of theoretical models (Hanson, Creswell, Plano Clark, Petska, \& Creswell, 2005). To examine Latino intercultural competence, the current study used two separate and sequential methodologies including qualitative semistructured interviews and a systematic ethnographic technique known as cultural consensus analysis (Romney, Weller, \& Batchelder, 1986).

Cultural consensus analysis measures the degree to which participants agree on the definition of some cultural domain (Dressler, Balieiro, \& dos Santos, 1998). Cultural consensus analysis assumes that cultural groups have a shared pool of knowledge distributed across social divisions and identifies this preferred cultural model through a form of reliability testing. Cultural consensus analysis also evaluates each participant's command of this cultural model, or expertise, compared with the aggregate. Finally, this analysis identifies the characteristics to a research question or cultural construct by estimating the distribution of the knowledge as it applies to participant expertise (Dressler et al., 2005). This technique permits the use of a relatively small number of key informants in the community, a necessity when developing new concepts within the Latino cultural experience (Marin \& Marin, 1991), while taking advantage of quantitative methods. Cultural consensus analysis has been used to examine beliefs about diabetes, AIDS, blood pressure, cervical and

Hispanic Journal of Behavioral Sciences, Vol 31, (2009): pg. 357-593. DOI. This article is C SAGE Publications and permission has been granted for this version to appear in e-Publications@ Marquette. SAGE Publications does not grant permission for this article to be further copied/distributed or hosted elsewhere without the express permission from SAGE Publications. 
breast cancer, pediatric respiratory symptoms, and asthma among Latinos and African Americans (Pachter et al., 2002). Developing a cultural model of Latino intercultural competence will provide significant insight into the community's definitions and beliefs about the mechanisms associated with effective cultural functioning.

The purpose of the current project was two-fold: (a) to discover and generate themes regarding the skills Latinos deem as necessary for successful intercultural interactions and (b) to derive a cultural model of Latino intercultural competence based on these emergent characteristics. To achieve these aims, qualitative methods were implemented to analyze information from semistructured interviews examining Latino intercultural competence. Then, cultural consensus analysis was conducted on a separate sample of participants to identify the functional elements of Latino intercultural competence. It was expected that a shared cultural model of Latino intercultural competence would emerge.

\section{Method}

\section{Qualitative Study: Phase 1}

Fifteen Latino individuals, from a moderately sized Midwestern city, volunteered and were interviewed to get an understanding of the skills necessary to engage successfully in the mainstream U.S. and Latino cultures. Participants were recruited through various community and University-based organizations that focused on or provided services for Latino individuals. Potential participants were identified by leaders in the respective organizations or because of their visible service in the Latino community. Participants were approached, given a brief description of the study, including confidentiality procedures, and invited to be interviewed. Participants provided both oral and written consent. Approval from the host institution's institutional review board was attained prior to data collection. Every attempt was made to attain a representative sample of individuals based on age, gender, and generation level.

The interviews were conducted by the principal investigator or by trained undergraduate research assistants in the language

Hispanic Journal of Behavioral Sciences, Vol 31, (2009): pg. 357-593. DOI. This article is (C) SAGE Publications and permission has been granted for this version to appear in e-Publications@ Marquette. SAGE Publications does not grant permission for this article to be further copied/distributed or hosted elsewhere without the express permission from SAGE Publications. 
preferred by the participant (i.e., English or Spanish). Although participants were encouraged to elaborate on their own experiences, the interview used a semistructured format with questions that prompted specific topic areas. For example, the first question read: "Think about a Latino/Hispanic person you consider to be 'successful' in the mainstream U.S. culture. What skills or characteristics does that person have?" A similar prompt was given with regards to success in the Latino community. These questions were chosen to allow the participant to create and identify their own definition of success and explain the features that would allow an individual to achieve such standards. The typical interview lasted 45 to 60 minutes.

The interviews were tape-recorded and transcribed word for word. Given that the majority of participants $(n=12)$ chose English for the language of the interview, the transcripts of the Spanish interviews were translated into English using a double translation procedure by two bilingual research assistants (see Marin \& Marin, 1991). Although translating qualitative interviews from the original language may restrict some of the richness of the data, analyzing the responses in English allowed for continuity across interviews. The participant responses were examined via strategies associated with grounded theory (Strauss \& Corbin, 1990). Specifically, the process of open coding was used in which "data are broken down into discrete parts, closely examined, and compared for similarities and differences" (p. 102). Initially, meaningful units of information, typically several sentences long, were identified that described discrete ideas or events. These units were then compared with each other and gradually grouped together based on shared characteristics to develop concepts. Related concepts were merged into category themes.

The research team that analyzed the qualitative data consisted of one Latino (the Principal Investigator), one Latina, and two European American women. The worldview and perspectives of the investigators play an important role in the analysis of qualitative data. Therefore, before the analysis process, the researchers discussed their values, biases, and assumptions. A Latino male served as an auditor by independently reviewing the emergent themes to determine that the categories adequately represented the information generated by the interviews. The entire research team then discussed potential disagreements until a consensus was reached. Once these themes

Hispanic Journal of Behavioral Sciences, Vol 31, (2009): pg. 357-593. DOI. This article is C SAGE Publications and permission has been granted for this version to appear in e-Publications@Marquette. SAGE Publications does not grant permission for this article to be further copied/distributed or hosted elsewhere without the express permission from SAGE Publications. 
describing intercultural competence were established, a list of 36 items was generated corresponding to the features of this construct. Every effort was made to develop items based on the participant responses. Two statements were later deemed poorly written and deleted bringing the final list to 34 items (see Table 1 ).

Table 1. Latino Intercultural Competence Items

\begin{tabular}{|c|c|}
\hline Item & $\begin{array}{c}\text { Participant } \\
\text { Agreement Scores }\end{array}$ \\
\hline \multicolumn{2}{|l|}{ Ambition/desire } \\
\hline $\begin{array}{l}\text { Having specific goals and a plan or strategy to } \\
\text { accomplish them }\end{array}$ & .96 \\
\hline Having a strong desire to be successful & .98 \\
\hline Knowing, deep down, that you are going to make it & .94 \\
\hline $\begin{array}{l}\text { Striving for more, always looking to be more } \\
\text { successful }\end{array}$ & .98 \\
\hline \multicolumn{2}{|l|}{ Relationship building } \\
\hline Being able to relate to all sorts of people & .87 \\
\hline $\begin{array}{l}\text { Having good relationships with your family and } \\
\text { friends }\end{array}$ & .94 \\
\hline Getting along with family & .94 \\
\hline \multicolumn{2}{|l|}{ Perseverance } \\
\hline $\begin{array}{l}\text { Not giving up or quitting even when things are not } \\
\text { going the way you are expecting }\end{array}$ & .89 \\
\hline Having strong will power or determination & .98 \\
\hline $\begin{array}{l}\text { To continue to do the that extra work, even though } \\
\text { circumstances are against you }\end{array}$ & .85 \\
\hline \multicolumn{2}{|l|}{ Hard work } \\
\hline Going above and beyond what is expected of you & .89 \\
\hline Not being lazy & .89 \\
\hline $\begin{array}{l}\text { Spending time working and looking for } \\
\text { opportunities }\end{array}$ & .96 \\
\hline \multicolumn{2}{|l|}{ Maintaining the traditional Latino culture } \\
\hline Embracing your culture for motivation & .87 \\
\hline Identification with one's past or roots & .87 \\
\hline $\begin{array}{l}\text { Maintaining the cultural practices, holidays, and/or } \\
\text { language of your country }\end{array}$ & .87 \\
\hline Keeping in touch with everyone in the family & .96 \\
\hline Having strong family values & .91 \\
\hline Understanding Latino cultural values like respect & .96 \\
\hline
\end{tabular}

Hispanic Journal of Behavioral Sciences, Vol 31, (2009): pg. 357-593. DOI. This article is (C) SAGE Publications and permission has been granted for this version to appear in e-Publications@Marquette. SAGE Publications does not grant permission for this article to be further copied/distributed or hosted elsewhere without the express permission from SAGE Publications. 


\begin{tabular}{|c|c|}
\hline Item & $\begin{array}{c}\text { Participant } \\
\text { Agreement Scores }\end{array}$ \\
\hline Creating networks or connections with others & .89 \\
\hline Knowing people in the community & .80 \\
\hline $\begin{array}{l}\text { Meeting new people and seeing how those people } \\
\text { can help you }\end{array}$ & .87 \\
\hline $\begin{array}{l}\text { Connecting with people so you can help them and } \\
\text { they can help you }\end{array}$ & .89 \\
\hline Networking with people who have been successful & .87 \\
\hline \multicolumn{2}{|l|}{ Communication } \\
\hline Being able to communicate well in English & .91 \\
\hline $\begin{array}{l}\text { Being able to express yourself in English and } \\
\text { Spanish }\end{array}$ & .91 \\
\hline Communicating what you are thinking to others & .74 \\
\hline \multicolumn{2}{|l|}{ Community-orientation and activity } \\
\hline $\begin{array}{l}\text { Understanding and learning the issues and } \\
\text { problems of the community }\end{array}$ & .82 \\
\hline $\begin{array}{l}\text { Providing service and leadership in the Latino } \\
\text { community }\end{array}$ & .74 \\
\hline Embracing the community and making it a priority & .67 \\
\hline $\begin{array}{l}\text { Being involved in the Latino/Hispanic community by } \\
\text { contributing your talents }\end{array}$ & .78 \\
\hline $\begin{array}{l}\text { Participating in the activities of the Latino/Hispanic } \\
\text { community and seeing how you can help }\end{array}$ & .74 \\
\hline $\begin{array}{l}\text { Spreading the word to everyone in the community } \\
\text { about activities, services, and so on }\end{array}$ & .80 \\
\hline $\begin{array}{l}\text { Motivation to help or give back to the } \\
\text { Latino/Hispanic community }\end{array}$ & .89 \\
\hline
\end{tabular}

\section{Cultural Consensus Analysis: Phase 2}

Following the procedures outlined by Dressler and Bindon (2000) and Dressler et al. (2005), 46 participated in this phase of the project. Individuals were recruited from various community-based organizations. They were given a brief description of the study, asked to participate, and provided oral and written consent. Approval from the host institution's Institutional Review Board was attained prior to data collection. Participants were asked to rate the list of 34 items (see Table 1) as to the importance of these skills to succeed in the U.S. mainstream and, separately, in the Latino community living in the United States. That is, participants were instructed to first rate the permission has been granted for this version to appear in e-Publications@Marquette. SAGE Publications does not grant permission for this article to be further copied/distributed or hosted elsewhere without the express permission from SAGE Publications. 
importance of the 34 items for "Latinos to succeed in the mainstream U.S. society." Then, they were asked to rate the importance of the same items for "Latinos to succeed in the Latino community living in the U.S." This procedure was chosen as a way of outlining the skills that were specific to the different contexts and types of cultural interactions. The ratings were originally based on a 5-point Likert-type scale from (0) not at all to (4) very important. To simplify the cultural consensus analysis, these ratings were later collapsed into a dichotomous variable indicating (0) not important (Likert-type ratings of 0-2) and (1) important (Likert-type ratings of 3-4). Preliminary analyses revealed a very high correlation $(r=.90 ; p<.001)$ between the ratings for the U.S. mainstream and the separate scores for competencies in the Latino culture. Given the extreme similarity between these ratings and to avoid redundancy, the cultural consensus analysis was conducted based on the dichotomous ratings of the intercultural competence items in response to engaging with the mainstream U.S. culture.

The first step in the cultural consensus analysis was to test for a shared cultural model of Latino intercultural competence. This analysis was conducted using the software program ANTHROPAC, which uses the participant ratings of importance as units of analysis and the informants as variables in a factor analysis. The degree of agreement on importance ratings is calculated between informants, thus, determining whether a single factor exists (Dressler \& Bindon, 2000). Romney et al. (1986) reported that if the ratio of the first eigenvalue to the second is 3.0 or greater, then this indicates sufficient agreement in the analysis. The second step of the cultural consensus analysis involves calculating the level of expertise for each participant. This analysis is essentially the factor loadings of each participant on the first factor indicating the magnitude of each informant's knowledge correlated with the aggregate knowledge of the group (Dressler \& Bindon, 2000). These coefficients of expertise are used in the third step of the cultural consensus analysis to calculate a weighted mean of each item's importance ratings. Averaged across the sample, these calculations give higher weight to participants who have higher cultural expertise. These composite scores are considered to be the shared characteristics of Latino intercultural competence.

Hispanic Journal of Behavioral Sciences, Vol 31, (2009): pg. 357-593. DOI. This article is (C) SAGE Publications and permission has been granted for this version to appear in e-Publications@ Marquette. SAGE Publications does not grant permission for this article to be further copied/distributed or hosted elsewhere without the express permission from SAGE Publications. 
An advantage of cultural consensus analysis includes the ability to derive estimates of shared knowledge using relatively small numbers of participant responses (Dressler et al., 2005). Determining sample size is based on the participants' average command or expertise of the cultural model, the confidence level, and the proportion of questions to be classified correctly (Romney et al., 1986). It has been reported that a minimum sample size of 29 participants is needed to perform an adequate cultural consensus analysis assuming an average 50\% (0.5) command or expertise of the cultural model, while attempting to classify $95 \%$ of the questions correctly with a 99\% confidence interval (Weller et al., 1999). The 46 participants who volunteered for this portion of the study were recruited to maintain a representative sample based on gender, generation level, and income.

\section{Results}

The participants for the qualitative phase of the project included 15 Latino adults (9 men, 6 women) who averaged approximately 35 years of age (range $=20-69$ ). Nine individuals reported being the first member of their family to move to the United States while the remaining participants were second generation or later. The majority ( $n=11$ ) of participants indicated being of Mexican descent. In terms of socioeconomic status, six individuals stated earning $\$ 20,000$ or more. The remaining participants chose not to divulge their annual income or were students earning $\$ 10,000$ or less. Nevertheless, the student participants appeared to have a middle-class background based on the University setting in which they were recruited. The average number of years living in the United States was approximately 16 but ranged from 2 to 44 years.

For the cultural consensus analysis phase, 46 Latino adults ( 22 men, 24 women) rated the intercultural competence items that were developed from the qualitative potion of the project. The mean age was approximately 35 years (range $=18-65$ ). Sixteen individuals were members of the first generation to live in the United States while 21 participants were second generation or later. All participants selfidentified themselves as Mexican or Mexican American. This sample consisted of 10 individuals earning an annual income of less than

Hispanic Journal of Behavioral Sciences, Vol 31, (2009): pg. 357-593. DOI. This article is (C) SAGE Publications and permission has been granted for this version to appear in e-Publications@ Marquette. SAGE Publications does not grant permission for this article to be further copied/distributed or hosted elsewhere without the express permission from SAGE Publications. 
$\$ 10,000,14$ earning between $\$ 10,000$ and $\$ 20,000,11$ earning between $\$ 20,000$ and $\$ 35,000$, and 11 earning more than $\$ 35,000$. The mean number of years living in the United States was approximately 12 years but ranged between 2 and 39 years. Thirtyfour individuals chose to rate the intercultural competence items in Spanish.

Cultural consensus analysis determines the extent to which participants agreed on the features of Latino intercultural competence. Cultural consensus analysis indicated that the ratio between the first and second eigenvalues was 12.8:1. These results reveal that a single factor exists indicating a shared cultural model of Latino intercultural competence in which the majority of participants concur. The average level of cultural knowledge was $0.65(S D=0.13)$. A significant gender difference was observed with men having higher cultural knowledge scores $(M=0.69 ; S D=0.11)$ than women $(M=0.60 ; S D=0.14)$, $t(44)=2.56, p<.05$. The participant agreement scores, or the percentage of participants which reported a particular item as "important," was used to rank order the importance of the intercultural competence categories. Discussed below are the themes that emerged from the qualitative content analysis and their level of importance according to the mean participant agreement scores of the cultural consensus analysis.

\section{Ambition and Desire to Succeed}

The cultural consensus analysis revealed that the items pertaining to the category of Ambition and Desire to Succeed received the highest scores of participant agreement $(M=0.97)$ suggesting that this theme is a key component to intercultural competence. As an emergent theme from the qualitative portion of the project, this category was defined as having realistic goals, dreams, and/or aspirations along with the strong drive or passion to achieve. That is, participants talked about the importance of having specific goals and the notion of continuing to better their situation. Simply stated, one 20-year-old man said, "I would say their ability to strive for more, and always looking to be more successful, basically." Another participant, a 27-year-old man, discussed this idea further and indicated

Hispanic Journal of Behavioral Sciences, Vol 31, (2009): pg. 357-593. DOI. This article is (C) SAGE Publications and permission has been granted for this version to appear in e-Publications@ Marquette. SAGE Publications does not grant permission for this article to be further copied/distributed or hosted elsewhere without the express permission from SAGE Publications. 
An ambitious person is a person that is thinking about accomplishing great things, great goals. Not merely finding a job that earns maybe $\$ 30,000$ a year but a person who is thinking about being the head ... could be a company or could be a leader of a social group ... [it is these people] that are always thinking about becoming managers of an organization whatever it may be.

These excerpts illustrate the idea that an interculturally competent Latino is successful, in part, by applying an achievement orientation to the adaptation process. That is, Latinos, regardless of whether they are immigrant or U.S.-born, are effective cultural navigators when they establish realistic goals, a plan to accomplish the goals, and a desire to overcome potentially difficult circumstances.

\section{Interpersonal Connections}

Some of the participants who were interviewed reported that an essential aspect of successful cultural navigation involved establishing and maintaining Interpersonal Connections. Within this broader category, individuals spoke of Relationship Building and Networking. Relationship building was defined as the willingness to interact and develop interpersonal connections with both Latinos and non-Latinos. For instance, one 32-year-old man stated, "And then obviously, having good relationships within your family, within your friends, being able to relate to all sorts of people is the key ingredient to becoming successful." Another individual, a 25-year-old, indicated,

I think a lot of it is the relationship part of it. This person kind of knows both ends of it. The culture of the United States and the culture of the United States or Mexico and so he has meshed it together. He is able to relate to the U.S. culture and also the Hispanic culture. So I would say, yeah, just that relationship building with different types of people.

This particular quote illustrates the idea that the cultural learning process occurs, in part, through the interpersonal relationships that are established in each culture. As such, this sense of interconnectedness becomes an important component of not only acquiring cultural content but establishing social support networks. According to the cultural consensus analysis, the Relationship Building

Hispanic Journal of Behavioral Sciences, Vol 31, (2009): pg. 357-593. DOI. This article is (C) SAGE Publications and permission has been granted for this version to appear in e-Publications@ Marquette. SAGE Publications does not grant permission for this article to be further copied/distributed or hosted elsewhere without the express permission from SAGE Publications. 
category items ranked as the second most important aspect of intercultural competence as calculated by the mean participant agreement scores $(M=0.92)$.

Another theme within Interpersonal Connections involved Networking or knowing people who have been successful and/or having mentors. For example, a 67-year-old woman indicated, "having a large group of people of not friends, but people that they know and they do business with. One person recommends another, one person can give you an idea that you can pursue." Thus, networking involves not just maintaining friendships but establishing contacts within the community. In terms of cultural consensus analysis, the Networking category items ranked as the fourth highest in terms of mean participant agreement scores $(M=0.86)$.

\section{Perseverance and Hard Work}

During their qualitative interviews, several participants talked about characteristics associated with perseverance or having the persistence, dedication, and willpower to continue even through tough circumstances. Participants described interculturally competent individuals as people who do not quit, do not take no for an answer, and have strong willpower. For instance, a 25-year-old participant said,

After my parents had a divorce ... she [my mother] came out to the United States with my brother and I so she not only worked full time but she would go to school full time at night and, characteristics I saw there were, you know, determination, sacrifice, she had to give a lot of sacrifice in order to get where she is at now.

As illustrated in this and many other participant statements is the underlying assumption that Latinos are going to face many hardships but that interculturally competent Latinos persist and continue to do extra work in order to achieve their goals. On a similar note, participants described Hard work, or going above and beyond, as another important concept of intercultural competence. A 67-year-old woman indicated,

Hispanic Journal of Behavioral Sciences, Vol 31, (2009): pg. 357-593. DOI. This article is (C) SAGE Publications and permission has been granted for this version to appear in e-Publications@ Marquette. SAGE Publications does not grant permission for this article to be further copied/distributed or hosted elsewhere without the express permission from SAGE Publications. 
If you think a job as a place where you go to get a salary, you are always going to be an employee, waiting for your paycheck. That's it. You have to be creative. Never be afraid to take an extra step and do a little more than you're required.

According to the participant agreement scores of the cultural consensus analysis, Perseverance $(M=0.91)$ and Hard work $(M=$ 0.91 ) both ranked as the third highest categories in terms of importance to succeed in the mainstream U.S. and Latino cultures.

\section{Maintaining the Traditional Latino Culture}

In discussing the characteristics of intercultural competence, many participants noted the importance of actively maintaining and identifying with one's culture of origin. That is, a key aspect of cultural success involved having pride in the Latino culture and keeping up with cultural traditions and values. For instance, a 69-year-old male participant stated, "I'm pretty sure most of them [competent Latinos] have kept their traditions and their culture which is something that I particularly like to make sure people do is not forget their culture, not forget their language or their customs." A 20-year-old male participant noted, "[competent Latinos] embrace their cultures, and because they do embrace their culture I think they derive some sort of, I guess, motivation for them to pull forward." Additionally, individuals spoke of the importance of upholding cultural values, particularly close ties with family members, as a way of facilitating the cultural transition process. The cultural consensus analysis revealed that the Maintaining Traditional Culture items tied for the third highest ranking, along with Perseverance and Hard work, according to participant agreement scores $(M=0.91)$.

\section{Communication}

Another theme that emerged from the qualitative interviews involved the ability to communicate effectively. Some participants noted the importance of learning to speak English particularly as it pertained to interactions with the mainstream U.S. culture. Others highlighted the value of being bilingual and speaking both English and Spanish. Beyond language acquisition, several participants indicated that being an active communicator with the ability to express one's

Hispanic Journal of Behavioral Sciences, Vol 31, (2009): pg. 357-593. DOI. This article is C SAGE Publications and permission has been granted for this version to appear in e-Publications@ Marquette. SAGE Publications does not grant permission for this article to be further copied/distributed or hosted elsewhere without the express permission from SAGE Publications. 
NOT THE PUBLISHED VERSION; this is the author's final, peer-reviewed manuscript. The published version may be accessed by following the link in the citation at the bottom of the page.

ideas is an essential skill. For instance, a 67-year-old participant stated, "speech and being able to communicate your ideas. It's not just speaking English, it's being able to communicate what you are thinking to others." The cultural consensus analysis showed that the Communication category received the second lowest participant agreement scores $(M=0.85)$.

\section{Community-Orientation and Activity}

The importance of the Latino community was evident in the qualitative interviews. Several participants discussed having a Community-Orientation or making the Latino community a priority by knowing the issues and feeling connected. Similarly, individuals spoke of being Community-Active or actively participating in and contributing to the Latino community. Many participants spoke of giving back to the community by providing service and leadership. This included volunteering for local organizations, being involved in community activities whether by planning or through dissemination of information. The cultural consensus analysis revealed that this category received the lowest participant agreement scores $(M=0.78)$. This suggests that Community-Orientation and Activity is not an essential component of the Latino intercultural competence cultural model.

\section{Discussion}

The principal objective of the current project was to delineate the features of Latino intercultural competence through a mixedmethods approach. The findings have advanced acculturation research by outlining the skills-based processes that facilitate intercultural interactions. The mixed-methodology allowed for the discovery of key characteristics that define intercultural competence along with the formulation of a shared cultural model of the construct. The current study provides some innovative findings including the attributes of intercultural competence, which emerged from the Latino community's definition of success, and the notion that this taps into a shared cultural experience that spans across socioeconomic background and generational status. The gender differences that emerged suggest that men may more easily recognize and identify the components of intercultural competence even though a common level of knowledge

Hispanic Journal of Behavioral Sciences, Vol 31, (2009): pg. 357-593. DOI. This article is (C) SAGE Publications and permission has been granted for this version to appear in e-Publications@ Marquette. SAGE Publications does not grant permission for this article to be further copied/distributed or hosted elsewhere without the express permission from SAGE Publications. 
exists regarding this construct. The cultural model of Latino intercultural competence includes a set of skills consistent with traditional cultural values along with attributes of self-efficacy. That is, respondents endorsed both a commitment to Latino values and an achievement motivation. In general, these results support Ogbu's (1981) notion of a native theory of success, which stipulates that members of ethnic minority groups develop their own definitions of cultural success. As such, effective cultural adaptation involves a delicate balance between competencies that emerge from both cultural contexts.

The most prominent theme in the cultural model of Latino intercultural competence involved Ambition and Desire to Succeed. This characteristic involved the ability to have realistic goals about living within two different cultures and continuing to strive for more despite the current circumstances. For instance, one of the participants in the qualitative study suggested that an incompetent Latino may be one who feels content simply by having moved to the United States but does very little to better their situation. Tyler et al. (1991) have stipulated that general competence involves a mastery-oriented problem-solving approach to negotiating life events that includes taking initiative, forbearance, and contributing to one's surroundings. Along these lines, Ambition and Desire to Succeed is a feature of intercultural competence that may reflect the ability to become an active agent in the adaptation process and suggests the importance of personal growth.

Another key aspect of Latino intercultural competence includes Relationship Building or the capacity to relate to family and friends. This notion is consistent with the Latino cultural values of familism, or the preference to maintain connected with family, as well as personalismo, which emphasizes the importance of having smooth interpersonal relationships through warm, friendly, and personal interactions (Santiago-Rivera, Arredondo, \& Gallardo-Cooper, 2002). In terms of intercultural competence, Relationship Building may be particularly vital for establishing social support networks during difficult or stressful circumstances. The qualitative analysis suggested that Relationship Building was more salient in terms of interactions with the mainstream U.S. whereas Networking was important within the Latino culture. As such, Networking may be a skill that allows

Hispanic Journal of Behavioral Sciences, Vol 31, (2009): pg. 357-593. DOI. This article is C SAGE Publications and permission has been granted for this version to appear in e-Publications@ Marquette. SAGE Publications does not grant permission for this article to be further copied/distributed or hosted elsewhere without the express permission from SAGE Publications. 
individuals to make use of the Latino community to gain cultural knowledge and take advantage of available resources. Interpersonal Connections as a whole are a valuable and multilayered aspect of successful cultural navigation and it could be that the differences associated with Relationship Building and Networking are indicative of the various cultural demands experienced in the different cultural contexts.

Within the Latino intercultural competence model, Perseverance represents the determination to persist particularly when experiencing difficult barriers. Recently, it was reported that intercultural competence concerns mediated the relationship between attributions to discrimination and depression among college-aged Latinos (Torres, 2009). It could be the case that it is the ability to persevere in the face of social injustice that allows interculturally competent individuals to succeed and which protects them from extreme psychological consequences. As components of the Latino intercultural competence model, Hard work and Maintaining the Traditional Latino Culture were often linked to other skills. For instance, during the qualitative interviews, Hard work was often discussed within the context of achieving individual goals. Maintaining the Traditional Latino Culture could be viewed as a frame of reference by which individuals approach person-environment interactions as well as a set of reliable and valued resources. It is likely that these components of Latino intercultural competence are independent but related aspects that contribute to effective cultural adaptation.

Although Communication was shown to be an aspect of the Latino intercultural competence model, it was not one of the highly ranked features. This suggests that intercultural competence is accounting for aspects of cultural adaptation beyond language-based acculturation factors. This is in contrast to the current thinking in the empirical literature which considers language fluency as the gold standard indicator of cultural adjustment. According to the shared cultural model, Community-Orientation and Activity was not an essential set of skills of Latino intercultural competence despite its emergence during the qualitative analysis. This could be due in part to the sample characteristics of the participants in the qualitative study who valued a strong service to the Latino community. This supports the use of cultural consensus analysis in addition to qualitative

Hispanic Journal of Behavioral Sciences, Vol 31, (2009): pg. 357-593. DOI. This article is (C) SAGE Publications and permission has been granted for this version to appear in e-Publications@Marquette. SAGE Publications does not grant permission for this article to be further copied/distributed or hosted elsewhere without the express permission from SAGE Publications. 
techniques as a way to triangulate vital information from multiple sources.

Typical of qualitative strategies, the current study is limited by relatively small sample sizes. Additionally, participants for both the qualitative interviews and the cultural consensus analysis were recruited from moderately-sized cities in the Midwest. The cultural model of intercultural competence identified by these informants may be different from those Latinos living in other parts of the United States. In terms of theoretical implications, the findings of the current study continue to advance acculturation research. Recent conceptualizations of acculturation and adaptation have focused on language-based factors and daily living preferences with minimal acknowledgement of efficacy or other competence-based attributes despite their importance as endorsed by a diverse group of Latinos. Practically, identifying intercultural competencies allows for the development and implementation of culturally-appropriate intervention efforts.

Overall, the current findings suggest that Latino intercultural competence contains multiple domains or sets of skills that promote successful cultural navigation and which are embedded within cultural values from both the Latino and U.S. cultures. This multifaceted process involves various competencies that are important for Latinos to master and which facilitate cultural adaptation. The ability to engage in a balanced set of intercultural competencies may be a mechanism that buffers Latinos from increased psychological problems, particularly those from later generations. Previous notions have suggested that competence for Latinos develop within a collectivistic and family-oriented value system (Santiago-Rivera et al., 2002). Although partially supported, the present findings reveal that Latino intercultural competence involves an integration of value systems that generate a set of skills necessary to succeed in both the U.S. mainstream and Latino cultures.

\section{Acknowledgments}

I would like to thank Steven Albert and David Rollock who provided feedback for earlier versions of this article. I would also like to thank the participants who volunteered to take part in this project.

Hispanic Journal of Behavioral Sciences, Vol 31, (2009): pg. 357-593. DOI. This article is C SAGE Publications and permission has been granted for this version to appear in e-Publications@Marquette. SAGE Publications does not grant permission for this article to be further copied/distributed or hosted elsewhere without the express permission from SAGE Publications. 
NOT THE PUBLISHED VERSION; this is the author's final, peer-reviewed manuscript. The published version may be accessed by following the link in the citation at the bottom of the page.

\section{Funding}

Portions of this research project were supported by the National Institute of Mental Health [grant \# R21 MH077735].

\section{Biography}

- Lucas Torres is an assistant professor in the Psychology Department at Marquette University. His research interests have involved examining the issues surrounding mental health disparities and delineating the components of the cultural adaptation process that serve as protective and risk factors of Latino mental health. He received his doctoral degree in clinical psychology from Purdue University.

\section{Footnotes}

Reprints and permission:

http://www.sagepub.com/journalsPermissions.nav

\section{Declaration of Conflicting Interests}

The author declared no conflicts of interest with respect to the authorship and/or publication of this article.

\section{References}

Berry JW. Conceptual approaches to acculturation. In: Chun KM, Organista PB, Marin G, editors. Acculturation: Advances in theory, measurement, and applied research. Washington, DC: American Psychological Association; 2003. pp. 17-37.

Dressler WW, Bindon JR. The health consequences of cultural consonance: Cultural dimensions of lifestyle, social support, and arterial blood pressure in an African American community. American Anthropologist. 2000;102:244-260.

Dressler WW, Balieiro MC, dos Santos JE. Culture, socioeconomic status, and physical and mental health in Brazil. Medical Anthropology Quarterly. 1998;12:424-446.

Hispanic Journal of Behavioral Sciences, Vol 31, (2009): pg. 357-593. DOI. This article is @ SAGE Publications and permission has been granted for this version to appear in e-Publications@ Marquette. SAGE Publications does not grant permission for this article to be further copied/distributed or hosted elsewhere without the express permission from SAGE Publications. 
NOT THE PUBLISHED VERSION; this is the author's final, peer-reviewed manuscript. The published version may be accessed by following the link in the citation at the bottom of the page.

Dressler WW, Borges CD, Balieiro MC, dos Santos JE. Measuring cultural consonance: Examples with special reference to measurement theory in anthropology. Field Methods. $2005 ; 17: 331-355$.

Hanson WE, Creswell JW, Plano Clark VL, Petska KS, Creswell JD. Mixed methods research designs in counseling psychology. Journal of Counseling Psychology. 2005;52:224-235.

LaFromboise T, Coleman HLK, Gerton J. Psychological impact of biculturalism: Evidence and theory. Psychological Bulletin. $1993 ; 114: 395-412$.

Marin G, Marin BV. Research with Hispanic populations. Newbury Park, CA: Sage; 1991.

Ogbu J. Origins of human competence: A cultural-ecological perspective. Child Development. 1981;52:413-429.

Pachter LM, Weller SC, Baer RD, Garcia JE, Garcia A, Trotter RT, et al. Variation in asthma beliefs and practices among mainland Puerto Ricans, Mexican-Americans, Mexicans, and Guatemalans. Journal of Asthma. 2002;39:119-134.

Padilla AM, Perez W. Acculturation, social identity, and social cognition: A new perspective. Hispanic Journal of Behavioral Sciences. $2003 ; 25: 35-55$.

Redfield R, Linton R, Herskovits $M$. Memorandum on the study of acculturation. American Anthropologist. 1936;38:149-152.

Rogler LH, Cortes DE, Malgady RG. Acculturation and mental health status among Hispanics: Convergence and new directions for research. American Psychologist. 1991;46:585-597.

Romney AK, Weller SC, Batchelder WH. Culture as consensus: A theory of culture and informant accuracy. American Anthropologist. 1986;88:313-338.

Hispanic Journal of Behavioral Sciences, Vol 31, (2009): pg. 357-593. DOI. This article is (C) SAGE Publications and permission has been granted for this version to appear in e-Publications@ Marquette. SAGE Publications does not grant permission for this article to be further copied/distributed or hosted elsewhere without the express permission from SAGE Publications. 
NOT THE PUBLISHED VERSION; this is the author's final, peer-reviewed manuscript. The published version may be accessed by following the link in the citation at the bottom of the page.

Santiago-Rivera AL, Arredondo P, Gallardo-Cooper M. Counseling Latinos and la familia: A practical guide. Thousand Oaks, CA: Sage; 2002.

Sodowsky GR, Lai EWM. Asian immigrant variables and structural models of cross-cultural distress. In: Booth A, Crouter AC, Landale $\mathrm{N}$, editors. Immigration and the family: Research and policy on U.S. immigrants. Mahwah, NJ: Lawrence Erlbaum; 1997. pp. 211-234.

Strauss A, Corbin J. Basics of qualitative research: Grounded theory procedures and techniques. Newbury Park, CA: Sage; 1990.

Torres L. Attributions to discrimination and depression among Latinos: The mediating role of competence. American Journal of Orthopsychiatry. 2009;79:118-124.

Torres L, Rollock D. Acculturative distress among Hispanics: The role of acculturation, coping, and intercultural competence. Journal of Multicultural Counseling and Development. 2004;32:155167.

Tyler FB, Brome DR, Williams JE. Ethnic validity, ecology, and psychotherapy: A psychological competence model. New York: Plenum Press; 1991.

Ward $C$. The $A, B, C$ s of acculturation. In: Matsumoto $D$, editor. The handbook of culture and psychology. New York: Oxford University Press; 2001. pp. 411-445.

Weller SC, Glazer M, Baer RD, Garcia de Alba Garcia JE, Pachter LM, Klein RE, et al. Latino beliefs about diabetes. Diabetes Care. $1999 ; 22: 722-728$.

Zea MC, Asner-Self KK, Birman D, Buki LP. The Abbreviated Multidimensional Acculturation Scale: Empirical validation with two Latino/Latina samples. Cultural Diversity and Ethnic Minority Psychology. 2003;9:107-126.

Hispanic Journal of Behavioral Sciences, Vol 31, (2009): pg. 357-593. DOI. This article is (C) SAGE Publications and permission has been granted for this version to appear in e-Publications@Marquette. SAGE Publications does not grant permission for this article to be further copied/distributed or hosted elsewhere without the express permission from SAGE Publications. 